\title{
MICROBIAL PROTEIN EXTRACTION FROM PALM OIL MILL EFFLUENT
}

\author{
NOR FAIZAH, J'*; NOORSHAMSIANA, A W'; WAN HASAMUDIN, W H'; $^{1}$ NAHRUL HAYAWIN, $Z^{1}$; \\ ROPANDI, M ${ }^{1}$; NUR ELIYANTI, A O ${ }^{1}$; ASTIMAR, A $A^{1}$ and ROHAYA, $\mathrm{M} \mathrm{H}^{1}$
}

\begin{abstract}
Palm oil mill effluent (POME) is abundantly produced during palm oil milling process and is treated for pollutant reduction without any revenue or profit. The main objective of this research was to evaluate POME as a substrate for microbial protein production and analyse the removal rate of pollutant. This study used hydrolysed POME containing fermentable sugars as carbon source for the cultivation of microbes. Raw POME was initially pre-treated with Celluclast ${ }^{\circledast}$ enzyme using the following conditions: concentration $\left(1.5 \%\right.$ to $5 \%$ v/v); incubation temperature $\left(45^{\circ} \mathrm{C}-55^{\circ} \mathrm{C}\right)$, rotation speed $(100-200 \mathrm{rpm})$ and $\mathrm{pH}(4.0-5.5)$. After pre-treatment, the hydrolysate contained $41.63 \mathrm{~g}_{\text {litre }}^{-1}$ reducing sugars with $56000 \mathrm{mg}_{\text {litre }}^{-1}$ chemical oxygen demand (COD). Baker's Yeast (Saccharomyces cerevisiae) was then cultivated onto the raw or hydrolysed POME at $30^{\circ} \mathrm{C}$ for seven days. The amount of yeast biomass produced was $28.92 \mathrm{~g} \mathrm{litre}^{-1}$ with $24.79 \%$ protein content. Adding to this, the COD value was reduced by $79.12 \%$. The yeast fermentation in hydrolysed POME recorded the highest increase in biomass and protein contents that of 3.44 and 7.74 folds, respectively. From the findings, it is revealed that POME is a promising raw material for microbial biomass protein production and simultaneously remove the pollutant from POME.
\end{abstract}

Keywords: biomass, microbial, palm oil mill effluent, single cell protein.

Received: 11 February 2021; Accepted: 15 July 2021; Published online: 28 September 2021.

\section{INTRODUCTION}

Malaysia processed more than 97.8 million tonnes of fresh fruit bunches (FFB) in 2018 (Kushairi et al., 2019). Apart from the production of crude palm oil, the mills also generated enormous amount of palm oil mill effluent (POME) every year. In general, $1 \mathrm{t}$ FFB would generate $0.67 \mathrm{~m}^{3}$ POME (Ma, 1999). As a result, more than 65 million $\mathrm{m}^{3}$ POME was discharged from the mills. Without treatment, raw POME is a polluting material with high chemical oxygen demand (COD) (51 $\left.000 \mathrm{mg}^{\text {litre }}{ }^{-1}\right)$, biological oxygen demand (BOD) (25 $\left.000 \mathrm{mg} \mathrm{litre}^{-1}\right)$ and total suspended solids (TSS) (18 $000 \mathrm{mg}$ litre $^{-1}$ ) (Nahrul Hayawin et al., 2017).

1 Malaysian Palm Oil Board, 6 Persiaran Institusi, Bandar Baru Bangi, 43000 Kajang, Selangor, Malaysia.

* Corresponding author e-mail: norfaizah@mpob.gov.my
Raw POME is basically a dark brown oily waste which consists of carbohydrate, protein, nitrogen $(\mathrm{N})$, lipids, minerals and other nutrients. Dried POME contains $39.3 \%$ cellulose and $24.6 \%$ hemicellulose (Khaw et al., 2008). Conventionally, POME is treated using the open pond system consisting of a cooling pond, an acidification pond, and the anaerobic and aerobic ponds. However, this system has its limitation where the BOD value is merely managed to reduce from $25000 \mathrm{mg}$ litre ${ }^{-1}$ to $50-100 \mathrm{mg}$ litre $^{-1}$. Many advanced technologies on POME treatment are being introduced including membrane ultrafiltration (Numan et al., 2019), membrane nanofiltration (Ali Amat et al., 2015), electrocoagulation (Nasrullah et al., 2018), and a hybrid system that combines the activated carbon adsorption and ultrasound cavitation (Parthasarathy et al., 2016). However, these advanced systems require very high capital and operating costs without returning any profits to the palm oil millers although they are very effective in reducing $\mathrm{BOD}, \mathrm{COD}, \mathrm{TSS}$ and colour. 
Alternatively, these waste streams can be converted from an economic liability into a source of revenue. POME could be converted via bioconversion into value-added products such as bioenergy and biochemical. The high compositions and concentrations of carbohydrate, protein, $\mathrm{N}$, lipids, minerals and other nutrients in POME make it possible to reuse the effluent for biotechnological processing (Nurul Adela et al., 2020). Therefore, researchers are starting to propose on recovering high value products from POME in order to increase the revenue of the palm oil millers and at the same time will promote sustainable oil palm industries (Chia et al., 2020). The recovery processes mostly practised in mills include biogas capture and biomass co-composting. Numerous attempts have been made to utilise POME in composting such as through vermicomposting and co-composting with empty fruit bunch (EFB) and decanter cake (Nahrul Hayawin et al., 2017). Another sustainable approach on POME utilisation is as a substrate for microbial fermentation and cultivation. For instance, microalgae can be cultivated in POME for bioremediation as well as a feedstock for biodiesel production (Kamyab et al., 2015). Furthermore, hydrolysed POME could be used to produce bioflocculant via POME-isolated Bacillus marisflavi cultivation. The resulted bioflocculant is potentially be used for wastewater treatment and algae recovery (Nurul Adela et al., 2016; 2020).

Another potential approach for resource recovery from POME is for production of single cell protein (SCP). SCP refers to sources of mixed proteins extracted from pure or mixed cultures of microorganisms. It is one of high quality dietary products for animals feed such as ruminants, pig, chicken and aquaculture application that enable to replace soymeal and fishmeal due to its high protein and nutrient content (Patelski et al., 2020; Sharif et al., 2021). Crude SCP which is also termed as bioprotein, microbial protein or biomass are widely produced from agricultural waste sources such as molasses, dairy waste, fruit waste, starch rich waste, bran, poultry waste etc. (Spalvins et al., 2018). SCP produced from different microbes has high protein content $(30 \%-70 \%)$ as compared to different green plants and animal sources. Previously, several types of microorganisms have been studied for the production of SCP such as yeast, bacteria, fungi and algae (Anupama and Ravindra, 2000). Microorganisms that are widely used in SCP production include Candida utilis and Saccharomyces cerevisiae since both microorganisms are safe for consumption. For instance, Saccharomyces cerevisiae that is produced in undiluted POME is able to produce $4.42 \mathrm{~g}$ litre $^{-1}$ protein biomass with $27 \%$ protein content. Another study by Izah (2018) highlights the cultivation of Saccharomyces cerevisiae in palm oil and cassava mill effluent. Based on proximate composition the results are also promising especially with protein content which is higher than $17 \%$ but with low yield (approximately $4 \mathrm{~g} \mathrm{litre}^{-1}$ ).

Since POME contains insoluble carbohydrates with high molecular weight compounds such as cellulose, hemicellulose and starch, it requires pretreatments to hydrolyse the complex carbohydrates in POME prior to fermentation to aid or speed up the microbial process (Nurul Adela et al., 2016). Khaw et al. (2008) has determined that POME solid contains about $39.3 \%$ cellulose and $24.6 \%$ of hemicellulose and these can be converted to fermentable sugars through hydrolysis process. Pre-treatments could disrupt the structure of lignocellulosic materials, hence releasing more reducing sugars which enhance the production of biochemicals. For instance, the sugar content in POME treated with cellulase enzyme increased from 12.45 to $27.13 \mathrm{~g} \mathrm{litre}^{-1}$ (Nurul Adela et al., 2016). Xylanase enzyme enables the release of sugars from hemicellulose in POME prior to biogas production and improves the hydrolytic reaction that increases the methane production (Prasertsan et al., 2017). Cellulolytic fungi such as Trichoderma harzianum and Mucor hiemalis are added in order to convert carbohydrate polymers in POME into fermentable sugar prior to yeast fermentation for bioethanol production (Alam et al., 2009). It was also reported that alkaline pre-treatment by using $2.58 \%$ sodium hydroxide $(\mathrm{NaOH})$ could increase the fermentable sugar content by $9.35 \%$ relative to untreated POME (Izzi et al., 2020). This showed that alkaline pre-treatment is also one of viable pre-treatment methods in addition to enzymatic hydrolysis method.

However, exploration of POME as a substrate for microbial protein production is still lacking compared to bioenergy and microalgae. To date, very limited studies are available on the utilisation of POME for SCP production (Iwuagwu and Ugwuanyi, 2014). Therefore, the aim of this article was to evaluate POME, either in raw or hydrolysed form, as potential material for obtaining the yeast biomass and producing microbial protein as a crude SCP. The pollutant removal will also be quantified in terms of COD reduction. This approach may recover and utilise value-added products from the palm oil mills, particularly from POME before being discharged into water courses. Apart from generating profits, this approach will indirectly help to safeguard our environment.

\section{MATERIALS AND METHODS}

\section{Raw Materials}

Samples of mixed raw effluent (MRE) containing steriliser condensate and clarification underflow sludge were collected at the sludge pit from Palm 
Oil Mill Effluent Technology Centre (POMTEC), located in Negeri Sembilan, Malaysia. These samples were transported and kept under $4^{\circ} \mathrm{C}$.

Cellulase (Celluclast ${ }^{\circledR} 1.5$ litre FG) used in MRE hydrolysis was obtained from Novozyme (M) Sdn. Bhd. The enzyme is commercially produced from Trichoderma reesei with the activity of 700 endoglucanase units (EGU) $\mathrm{g}^{-1}$.

Dry yeast (Mauripan) was inoculated onto a basal medium consisting of glucose (50 $\left.\mathrm{g} \mathrm{litre}^{-1}\right)$, $\mathrm{MgSO}_{4} \cdot 7 \mathrm{H}_{2} \mathrm{O} \quad\left(0.025 \mathrm{~g}\right.$ litre $\left.^{-1}\right)$, monopotassium

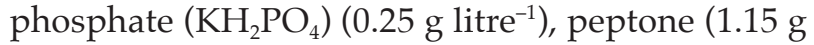
litre $\left.^{-1}\right)$ and yeast extract $\left(2.5 \mathrm{~g}\right.$ litre $\left.^{-1}\right)$. All chemicals were purchased from local companies with $100 \%$ purity and for molecular biology grade. The $\mathrm{pH}$ of the prepared medium was adjusted to 5.0 and sterilised in an autoclave (model 50HV Hirayama) at $121^{\circ} \mathrm{C}$ for $15 \mathrm{~min}$ (Keturah et al., 2014).

\section{Methods}

In this study, raw POME was firstly enzymatically hydrolysed using cellulase enzyme in order to release fermentable sugars as a carbon source for the microbe's growth. One-factor-at-time (OFAT) method was used to determine the optimal conditions in producing fermentable sugars via POME hydrolysis. $\mathrm{NaOH}$ was also added prior to POME hydrolysis to condition the substrate's $\mathrm{pH}$ as well as to enhance the fermentable sugar production. Then, the cultivation of Saccharomyces cerevisiae was performed in various $\mathrm{POME}$ to basal medium ratios that are 0:100, 50:50 and 100:0. Moreover, the biomass yield, protein content and COD reduction were determined to identify the most suitable POME medium for maximum microbial protein production and pollutant removal. Analytical measurements were performed based on DOE standard method and APHA method. The overall process flow for
MRE utilisation for microbial biomass protein production is illustrated in Figure 1.

\section{Compositional Analysis of Mixed Raw Effluent (MRE)}

A total of $200 \mathrm{ml}$ sludge POME was filtered using cellulose filter (Whatman Filter No. 1) and put in a thimble and dried overnight in an oven. The dried solid MRE was then subjected to Soxhlet extraction with $130 \mathrm{ml}$ petroleum ether for $4 \mathrm{hr}$ to remove residual oil and extracts. The solid residue was then dried overnight at $60^{\circ} \mathrm{C}$ to remove traces of the solvent. The dried solid residue was then analysed for hemicellulose, cellulose and lignin as described by Ayeni et al. (2015). The cellulose content $(\% \mathrm{w} / \mathrm{w})$ was calculated, assuming that oil and extractives, hemicellulose, lignin and cellulose were the only solid components in the entire mixed raw POME. The calculation is shown in Equation (1).

Cellulose (\% w/w): $100 \%$ -

hemicellulose - lignin -

(oil + extractives)

Equation (1)

\section{Enzymatic Hydrolysis for Mixed Raw Effluent (MRE) Pre-treatments}

A volume of $100 \mathrm{ml}$ MRE samples were adjusted to $\mathrm{pH} 4.7$ (using $0.1 \mathrm{M}$ citrate buffer or $0.1 \mathrm{M}$ $\mathrm{NaOH}$ ), followed by the addition of $1 \mathrm{ml}$ cellulase enzyme. The samples were then incubated at $50^{\circ} \mathrm{C}$ with $150 \mathrm{rpm}$ rotation for $24 \mathrm{hr}$ (Noorshamsiana et al., 2013). After the incubation process, the POME hydrolysate mixture was then sterilised at $121^{\circ} \mathrm{C}$ for $15 \mathrm{~min}$. Parameters for the incubation were varied as follows: enzyme dosages ( $1 \%$ to $5 \% \mathrm{v} / \mathrm{v})$, temperatures $\left(45^{\circ} \mathrm{C}-55^{\circ} \mathrm{C}\right)$, agitation rate $(100-200$ rpm) and $\mathrm{pH}(4.0-6.0)$.

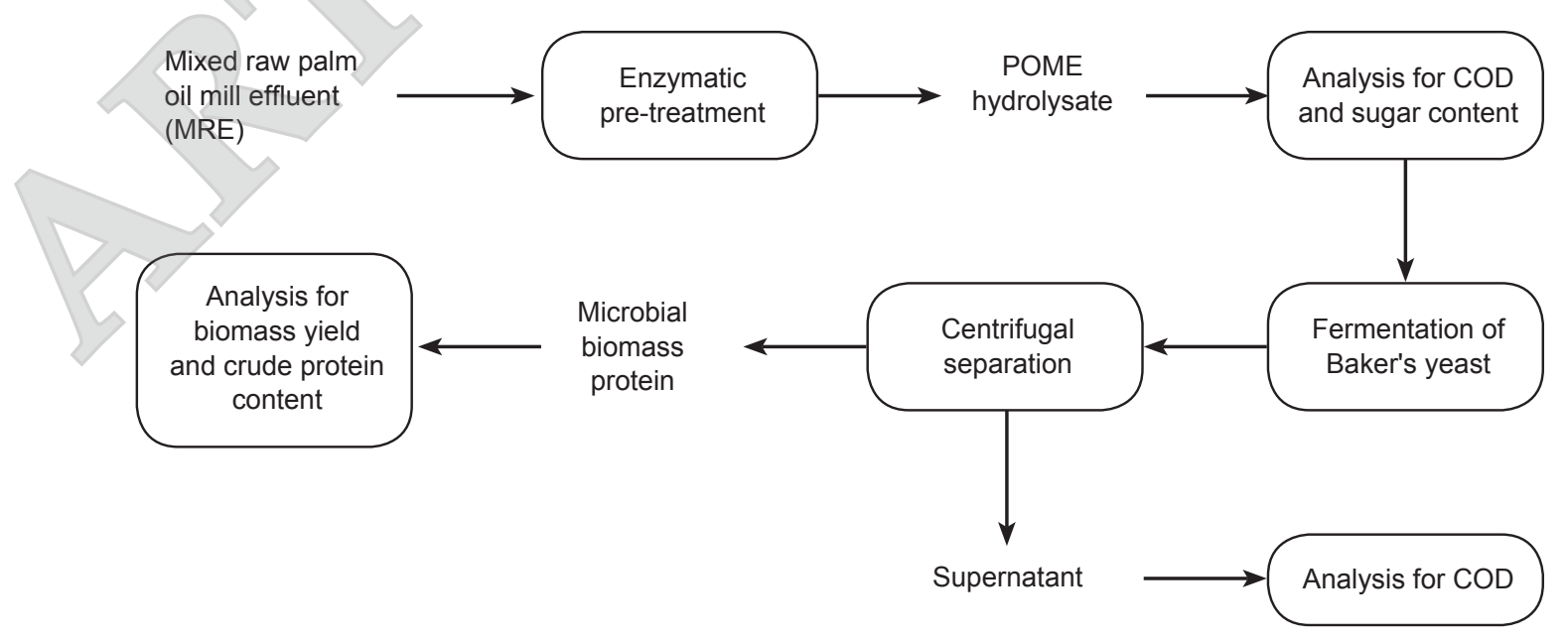

Figure 1. Process flow for mixed raw palm oil mill effluent (POME) utilisation for microbial biomass protein production. 


\section{Isolation of Baker's Yeast into Pure Culture}

An amount of $1 \mathrm{~g}$ dry yeast was stirred in 100 $\mathrm{ml}$ distilled water in sterile condition inside laminar flow cabinet to prevent contamination. After 10-fold serial dilutions, $0.1 \mathrm{ml}$ of the suspension was spread onto the surface of malt extract agar plates. Visible individual yeast colony was transferred onto new agar plates for seed culturing. All yeast cultures were incubated at $30^{\circ} \mathrm{C}$ for $48 \mathrm{hr}$.

\section{Yeast Cultivation in Mixed Raw Effluent (MRE)}

One full loop of pure single colony from the seed culture was inoculated into $10 \mathrm{ml}$ growth medium (GM) in a 50-ml Falcon tube overnight to promote yeast growth. The production of crude SCP was performed in a 250-ml flask using $100 \mathrm{ml}$ POME medium or GM. The flask was inoculated with $10 \%$ $(\mathrm{v} / \mathrm{v})$ of the overnight seed culture and incubated at $30^{\circ} \mathrm{C}$ with agitation at $150 \mathrm{rpm}$ for seven days using a rotary incubator shaker (MaxQ Mini 4450, Thermo Fisher Scientific, USA). After seven days, the fermentation was halted and the biomass was harvested. The resulting yeast biomass was subjected to centrifugal separation prior to the protein content analysis. The residual supernatant was collected for COD measurement.

The effect of medium composition for fermentation was studied by varying the POME to GM ratio. Two types of POME medium, i.e. POME hydrolysate and untreated MRE were used in the fermentation medium preparation. The compositions of fermentation medium are shown in Table 1.

\section{Chemical Oxygen Demand (COD) Analysis}

Samples were diluted 10 times with distilled water for COD analysis. A volume of $0.2 \mathrm{ml}$ diluted samples were transferred into the High Range Plus COD reagent vial (HACH, COD range 1500-15 000 ppm). The mixtures of samples and reagents were heated in the reactor at $150^{\circ} \mathrm{C}$ for $2 \mathrm{hr}$ and then cooled to room temperature. The COD was then measured using a HACH DR890 colorimeter (APHA, 2018).

\section{Reducing Sugar and Glucose Content}

The reducing sugar content was measured by dinitrosalicylic acid (DNS) method (Miller, 1959). Approximately $1.5 \mathrm{ml}$ sample was centrifuged at $5000 \mathrm{rpm}$ for $20 \mathrm{~min}$ and $1 \mathrm{ml}$ supernatant was decanted into a boiling tube. After adding $2 \mathrm{ml}$ DNS reagent, the solution was then boiled in a water bath for $10 \mathrm{~min}$. Then, the solution was made up to $10 \mathrm{ml}$ with distilled water. The absorbance of the sample solution was measured at $540 \mathrm{~nm}$ using a UV-Visible spectrophotometer. The DNS calibration curve was developed using glucose standard concentrations of $0,0.2,0.4,0.6,0.8$ and 1.0 g litre $^{-1}$.

\section{Biomass Concentration}

The biomass was collected by centrifuging the culture medium at $5000 \mathrm{rpm}$ for $20 \mathrm{~min}$. The supernatant was discarded and the pellet was washed several times with distilled water and then dried in an oven at $80^{\circ} \mathrm{C}$ for $24 \mathrm{hr}$ (Keturah et al., 2014). The biomass concentration or biomass yield was quantified in $\mathrm{g}$ litre ${ }^{-1}$.

TABLE 1. COMPOSITIONS OF FERMENTATION MEDIUM FOR SINGLE CELL PROTEIN PRODUCTION

\begin{tabular}{|c|c|c|c|c|c|c|c|c|}
\hline \multirow{2}{*}{ Composition } & \multicolumn{3}{|c|}{ The ratio of POME: Growth medium } & \multicolumn{5}{|c|}{ Composition of nutrient in fermentation medium ( $\mathrm{g}$ in $100 \mathrm{ml}$ ) } \\
\hline & $\begin{array}{c}\text { Untreated } \\
\text { MRE } \\
(\mathrm{ml})\end{array}$ & $\begin{array}{c}\text { POME } \\
\text { hydrolysate } \\
(\mathrm{ml})\end{array}$ & $\begin{array}{l}\text { Growth } \\
\text { medium } \\
(\mathrm{ml})\end{array}$ & Glucose & $\begin{array}{l}\text { Yeast } \\
\text { extract }\end{array}$ & Peptone & $\mathrm{KH}_{2} \mathrm{PO}_{4}$ & $\mathrm{MgSO}_{4}$ \\
\hline $\begin{array}{c}\text { Reference } \\
\text { Control } 1 \text { (CHP) }\end{array}$ & & 100 & 100 & 5 & 0.3 & 0.5 & 0.1 & 0.05 \\
\hline Control $2(\mathrm{CP})$ & 100 & & & & & & & \\
\hline 1 & & 50 & 50 & 2 & 0.3 & 0.5 & 0.1 & 0.05 \\
\hline 2 & & 100 & & & & & & \\
\hline 3 & & 100 & & 2 & 0.3 & 0.5 & 0.1 & 0.05 \\
\hline 4 & 50 & & 50 & 2 & 0.3 & 0.5 & 0.1 & 0.05 \\
\hline 5 & 100 & & & & & & & \\
\hline 6 & 100 & & & 2 & 0.3 & 0.5 & 0.1 & 0.05 \\
\hline
\end{tabular}

Note: POME - palm oil mill effluent; MRE - mixed raw effluent; CP - control sample for untreated MRE; CHP - control sample for POME hydrolysate. 


\section{Crude Protein}

Protein content (\%) was determined by total nitrogen (TN) method with traditional conversion factor of 6.25 to convert nitrogen into protein content (Maehre et al., 2018). The TN analysis was conducted using Dumas combustion method (Durmatherm, Gerhardt) with reactor temperature at $980^{\circ} \mathrm{C}$. During the determination of TN, oxygen was used for combustion while helium was used as the carrier gas. This method was selected due to shorter analysis times, ease of operation and improved safety compared to the Kjeldahl method but with similar precision (Müller, 2017). The protein yield ( $\mathrm{g} \mathrm{litre}^{-1}$ ) was calculated by multiplying the biomass yield $\left(\mathrm{g}\right.$ litre $\left.^{-1}\right)$ and protein content $(\%)$ of the biomass.

\section{RESULTS AND DISCUSSION}

\section{Compositional Analysis of Mixed Raw Effluent (MRE)}

The cellulose, hemicelluloses, lignin, oil content and moisture content were analysed prior to POME pre-treatment. Results obtained from the triplicate analysis revealed that the MRE contained water (90\%-95\%), solids (4\%-7\% dry weight), as well as oil and extractives (2\%-3\% dry weight). The lignocellulosic content of solid fraction in MRE was quantified. The solid MRE contained 44\%$58 \%$ cellulose, $7 \%-11 \%$ hemicellulose, and 27\%-43\% lignin (Table 2). It is believed that high lignin content in POME contributed to the dark brownish POME colour together with tannin, humic acid and fulvic acid-like substance as well as phenolic compounds
(Zahrim et al., 2014). The cellulose amount was higher than the value reported by Khaw et al. (2008) whereas the hemicellulose content was comparable with Prasertsan et al. (2017). These findings may be due to the differences in sampling points, mills processes, and other factors (oil palm age and locality). Moreover, Table 2 shows the organic content (measured as COD), total solids, crude protein, TN, reducing sugars, and glucose in MRE. The measured values obtained in this study were within the range when compared to previous studies. Apart from organic constituents, raw POME contains minerals and other nutrients such as phosphorus, potassium, calcium, and magnesium (Nahrul Hayawin et al., 2017). The available cellulose and hemicellulose in POME can be converted into simple sugars and further utilised as fermentation media, while the available minerals and nutrients may be useful for microbial growth.

\section{Pre-treatment of Mixed Raw Effluent (MRE) for Fermentable Sugar Production}

Polysaccharides in lignocellulosic materials are made from long homopolymer chain of glucose units connected by beta acetyl linkages. The low digestibility of lignocellulosic biomass for conversion into fermentable sugars is usually due to its lignin content, acetyl groups, and crystallinity. Therefore, physical and chemical pre-treatments followed by enzymatic hydrolysis are essential in order to improve the accessibility of the sugar components (Silvamany et al., 2015). Enzymatic MRE pretreatment using commercial cellulase enzymes were carried out. Optimisation of enzymatic hydrolysis was carried out using OFAT method by varying one

TABLE 2. COMPOSITIONS OF MIXED RAW PALM OIL MILL EFFLUENT

\begin{tabular}{lccc}
\hline Parameters & Unit & This study & Other studies \\
\hline COD & $\mathrm{mg} \mathrm{litre}^{-1}$ & $48000-91300$ & $52000-114800$ \\
Moisture & $\%$ & $90-95$ & $95-96$ \\
Total solid & $\mathrm{g} \mathrm{litre}^{-1}$ & $29-70$ & $38-73$ \\
Total carbohydrate & $\%$ & $\mathrm{NA}$ & $22.27-29.55$ \\
Crude protein & $\%$ & $8.40-17.63$ & $12.31-12.75$ \\
Total nitrogen & $\mathrm{mg} \mathrm{litre}{ }^{-1}$ & $536-1295$ & $420-8540$ \\
Reducing sugar & $\mathrm{g}$ litre & $1.53-12.45$ \\
Glucose & $\mathrm{g}$ litre & $0.87-1.01$ \\
Cellulose & $\%$ dry weight & $5.29-14.79$ & $38-39$ \\
Hemicellulose & $\%$ dry weight & $0-2.32$ & $23-24$ \\
Lignin & $\%$ dry weight & $44-58$ & $22-26$ \\
\hline
\end{tabular}

Source: Kamal et al., 2012; Khaw et al., 2008; Nahrul Hayawin et al., 2017; Nurul Adela et al., 2016; Prasertsan et al., 2017; Saifuddin and Refal, 2014.

Note: NA - not analysed. 
factor while keeping other parameters fixed in each experiment. In the first experiment, temperatures were varied at $45^{\circ} \mathrm{C}, 50^{\circ} \mathrm{C}$ and $55^{\circ} \mathrm{C}$ while $\mathrm{pH}$, agitation, and enzyme dosage were fixed at 5.0, $150 \mathrm{rpm}$, and $1 \%(\mathrm{v} / \mathrm{v})$, respectively. Fermentable sugar production measured as reducing sugar content was optimum at $50^{\circ} \mathrm{C}$ incubation temperature (Figure 2). The optimum temperature for the reaction and stability of three components, namely, endoglucanase, cellobiohydrolase, and beta-glucosidase in Trichoderma sp. is between $50^{\circ} \mathrm{C}$ and $60^{\circ} \mathrm{C}$ (Mun et al., 2008). However, enzymatic hydrolysis activity becomes slower at $55^{\circ} \mathrm{C}$ and thus, producing less fermentable sugars.

In general, instead of using a buffer solution, MRE mixed with $\mathrm{NaOH}$ gave higher reducing sugar content. For instance, based on Figure 2, samples that were added with $100 \mathrm{ml} 0.1 \mathrm{M}$ of citrate buffer solution produced $13.14 \mathrm{~g} \mathrm{litre}^{-1}$ of fermentable sugars at incubation temperature of $50^{\circ} \mathrm{C}$. In contrast, samples that were added with $100 \mathrm{ml} 0.1 \mathrm{M} \mathrm{NaOH}$ produced about $34.78 \mathrm{~g} \mathrm{litre}^{-1}$ sugars. $\mathrm{NaOH}$ acts as a medium to adjust the $\mathrm{pH}$ which increases the amount of reducing sugars produced after the enzymatic hydrolysis. This finding is in agreement with Khaw et al. (2008) where lignin degradation by alkali will enhance the conversion of MRE into simple sugars. Alkali helps to promote hydrolysis and splitting of polymers into smaller molecules. During alkaline hydrolysis, the lignocellulosic compound swelled, leading to alteration of lignin structure and breaking of the ester and glycosidic chains (Noorshamsiana et al., 2017).

Further experiments were carried out by treating the samples with $100 \mathrm{ml} 0.1 \mathrm{M} \mathrm{NaOH}$ for $\mathrm{pH}$ adjustment. It was observed that the highest amount of fermentable sugars was produced when the $\mathrm{pH}$ of the substrate was at 4.7 (Figure 3). However, sugar production was not directly affected by the increment of enzyme concentration and agitation rate (Figures 4 and 5). Much lower enzyme loading was preferred in order to reduce the processing costs. Thus, the enzyme concentration of $1.0 \%(\mathrm{v} / \mathrm{v})$ which gave comparable sugar production was used. Although the COD values were not affected by all parameters, however, COD values increased with the production of fermentable sugars. Based on OFAT method, the optimum parameters obtained for enzymatic hydrolysis of MRE using cellulase enzyme were $\mathrm{pH} 4.7$, temperature $50^{\circ} \mathrm{C}$, agitation rate $150 \mathrm{rpm}$, and enzyme dosage of $1 \mathrm{ml} / 100 \mathrm{ml}$ MRE. MRE hydrolysate with reducing sugar content of about $41.63 \mathrm{~g} \mathrm{litre}^{-1}$ was produced whereas the COD value was $56800 \mathrm{mg}$ litre $^{-1}$, compared to control that produced only $12.44 \mathrm{~g}^{-1}$ litre $^{-1}$ of fermentable sugars (Figure 4). The fermentable sugars are utilised to complement glucose that is usually used in the preparation of conventional fermentation medium, due to the relatively high MRE hydrolysate reducing sugar content.

\section{Yeast Growth Profile in Hydrolysed POME}

The viable cell counts of the yeast isolate in the POME hydrolysate added with glucose, N source, and minerals are presented in Table 3 . The cell count can only be visible after $72 \mathrm{hr}$ cultivation. There was an intense growth of yeast after day 5 and day 6 of cultivation. However, after day 7, a reduction in viable cell count was recorded $\left(4.00 \times 10^{8} \mathrm{CFU}\right.$ $\mathrm{ml}^{-1}$ ). The mean viable cell counts of $S$. cerevisiae in POME hydrolysate were found to decrease after day 7 . The reduction in growth can be attributed to limiting nutrients and oxygen, arising from the depletion of nutrients and oxygen in the media. Autolysis is enhanced by the exhaustion of nutrients and oxygen (Ojokoh and Uzeh, 2005). Thus, yeast cultivation will stop at day 7 in order to obtain maximum biomass yield from the fermentation.

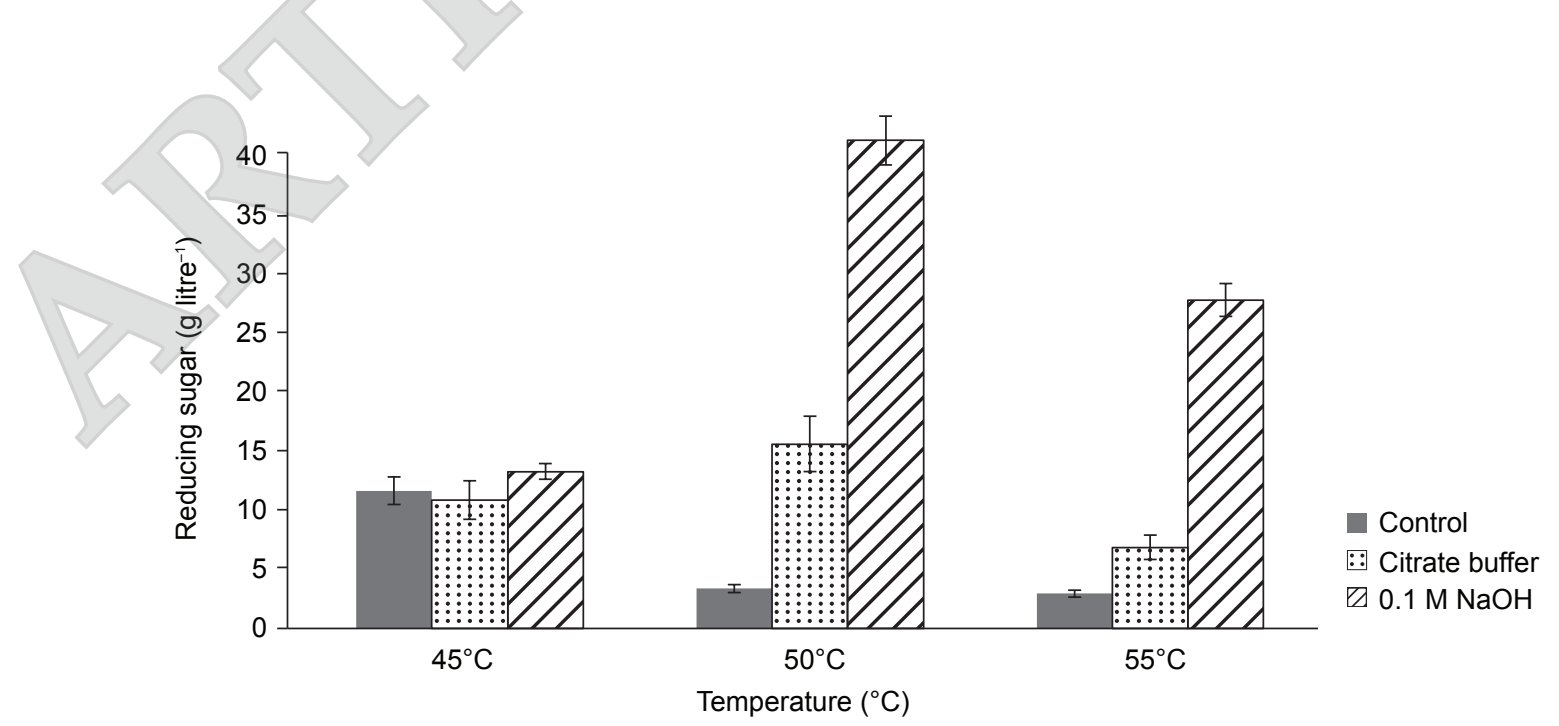

Figure 2. Effect of incubation temperature on reducing sugar concentration (enzyme dosage: $1 \mathrm{ml} 100 \mathrm{ml}$ substrate, pH: 4.7, agitation rate: $150 \mathrm{rpm}$ ). 


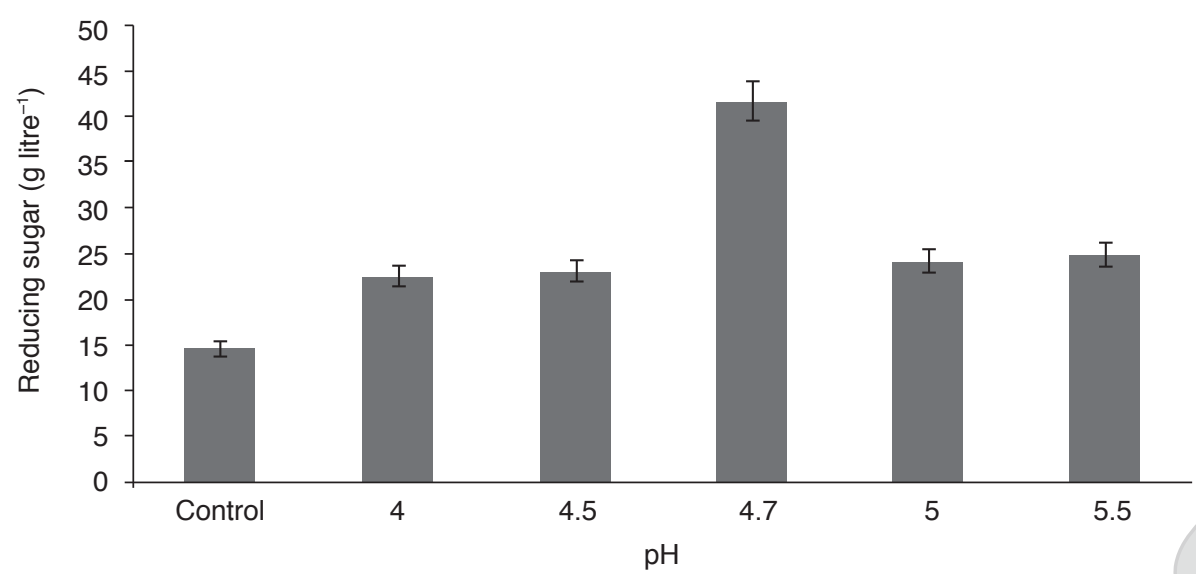

Figure 3. Effect of $\mathrm{pH}$ on fermentable reducing sugar production (enzyme dosage: $1 \mathrm{ml} / 100 \mathrm{ml}$ substrate, agitation rate: $150 \mathrm{rpm}$, incubation temperature: $50^{\circ} \mathrm{C}$ ).

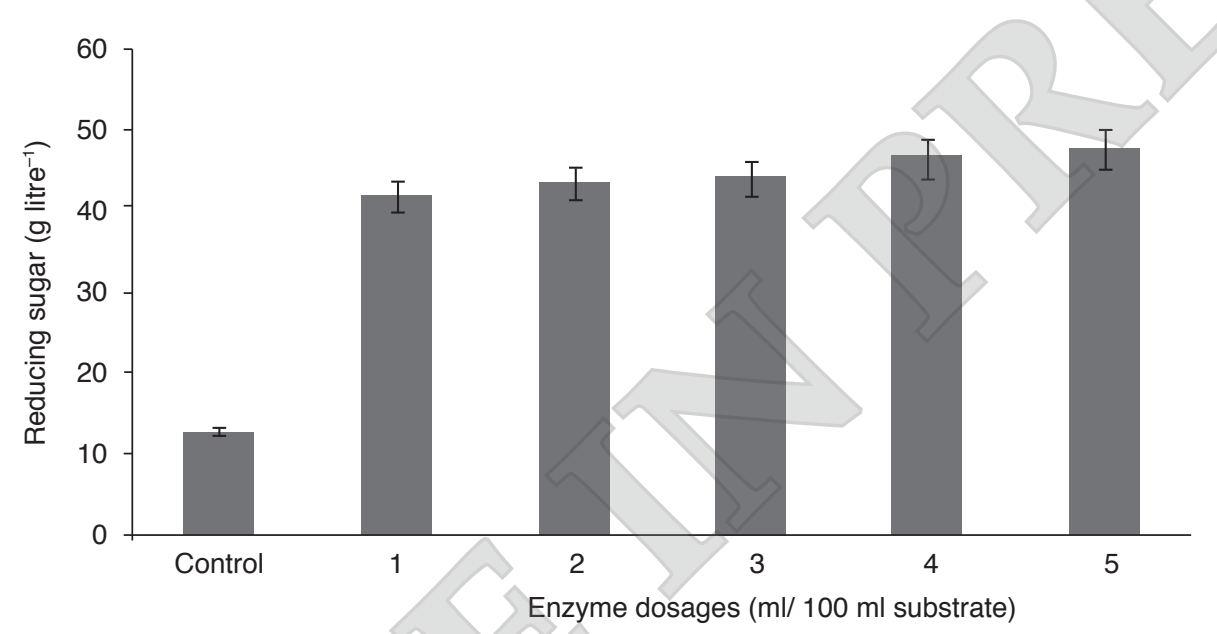

Figure 4. Effect of enzyme dosages on fermentable sugar production ( $p H: 4.7$, agitation rate: 150 rpm, incubation temperature: $50^{\circ} \mathrm{C}$ ).

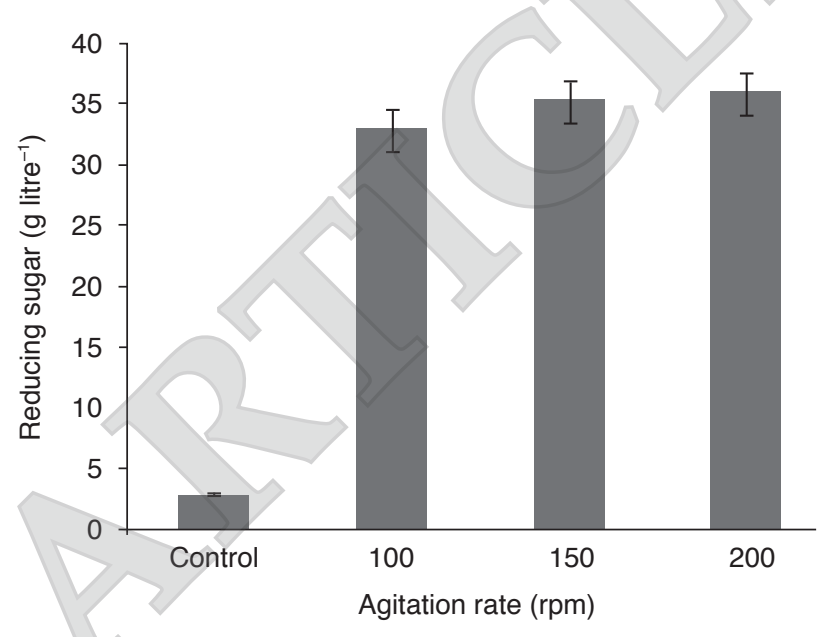

Figure 5. Effect of agitation rate on fermentable sugar production (enzyme dosage: $1 \mathrm{ml} / 100 \mathrm{ml}$ substrate, pH: 4.7, incubation temperature: $50^{\circ} \mathrm{C}$ ).

\section{Production of Microbial Biomass Protein with Different POME Compositions}

After 7 days of fermentation, the growth of Baker's yeast in control and experimental media
TABLE 3. VIABLE CELL COUNT OF Saccharomyces cerevisiae IN POME HYDROLYSATE MEDIUM DURING 7-DAYS INCUBATION

\begin{tabular}{cc}
\hline Day & $\mathrm{CFU} \mathrm{ml}^{-1}$ \\
\hline 1 & Not visible \\
2 & Not visible \\
3 & $5.00 \times 10^{7}$ \\
4 & $8.00 \times 10^{7}$ \\
5 & $2.04 \times 10^{8}$ \\
6 & $1.03 \times 10^{9}$ \\
7 & $4.00 \times 10^{8}$ \\
\hline
\end{tabular}

were determined by quantifying the biomass yield. The biomass yield, COD reduction, and protein content obtained after yeast fermentation in different medium containing hydrolysed MRE (POME hydrolysate) or untreated POME as well as supplemented fermentation medium are tabulated in Table 4. Compositions 1 to 3 consisted of POME hydrolysate as fermentation medium supplemented with nutrients as described in the 
TABLE 4. EFFECT OF DIFFERENT FERMENTATION MEDIUM ON BIOMASS YIELD, COD REDUCTION AND PROTEIN CONTENT

\begin{tabular}{|c|c|c|c|c|c|}
\hline Composition no. & Media & $\begin{array}{l}\text { Biomass yield } \\
\quad\left(\text { g litre }^{-1}\right)\end{array}$ & $\begin{array}{c}\text { COD reduction } \\
(\%)\end{array}$ & $\begin{array}{c}\text { Protein content } \\
\qquad(\%)\end{array}$ & $\begin{array}{l}\text { Protein yield } \\
\quad\left(\mathrm{g}_{\text {litre }}{ }^{-1}\right)\end{array}$ \\
\hline Reference & $100 \%$ GM & $29.51 \pm 0.35$ & $22.63 \pm 0.05$ & $58.63 \pm 0.95$ & $17.30 \pm 0.25$ \\
\hline $\mathrm{CHP}$ & Control hydrolysed POME & $8.34 \pm 0.32$ & $62.22 \pm 2.50$ & $11.05 \pm 0.04$ & $0.92 \pm 0.03$ \\
\hline $\mathrm{CP}$ & Control untreated MRE & $29.93 \pm 1.89$ & $59.87 \pm 1.47$ & $17.23 \pm 0.41$ & $5.45 \pm 0.44$ \\
\hline 1 & $50 \% \mathrm{HP}+50 \% \mathrm{GM}$ & $18.35 \pm 1.21$ & $55.39 \pm 1.00$ & $24.42 \pm 0.11$ & $4.52 \pm 0.30$ \\
\hline 2 & $100 \% \mathrm{HP}$ & $17.66 \pm 1.20$ & $68.32 \pm 2.50$ & $18.72 \pm 0.42$ & $3.21 \pm 0.20$ \\
\hline 3 & $\begin{array}{c}\mathrm{HP}+2 \% \text { glucose }+\mathrm{YE}+ \\
\text { Peptone }+ \text { minerals }\end{array}$ & $28.92 \pm 1.37$ & $79.12 \pm 1.87$ & $24.79 \pm 0.33$ & \\
\hline 4 & $50 \% \mathrm{UP}+50 \% \mathrm{GM}$ & $26.64 \pm 0.99$ & $56.98 \pm 2.30$ & $18.92 \pm 0.6$ & .34 \\
\hline 5 & $100 \%$ UP & $31.13 \pm 3.00$ & $62.85 \pm 2.50$ & $24.00 \pm 1.96$ & $78 \pm 0.51$ \\
\hline 6 & $\begin{array}{l}\mathrm{UP}+2 \% \text { glucose }+\mathrm{YE}+ \\
\text { Peptone }+ \text { minerals }\end{array}$ & $51.66 \pm 3.47$ & $56.07 \pm 2.70$ & 18.09 & \pm 0.79 \\
\hline
\end{tabular}

Note: POME - palm oil mill effluent; COD - chemical oxygen demand; CP - control sample for untreated MRE; CHP - control sample for POME hydrolysate; HP - hydrolysed POME; UP - untreated MRE; YE - yeast extract; GM - growth medium.

method section. Composition 3 which contained $100 \mathrm{ml}$ POME hydrolysate supplemented with $2 \mathrm{~g}$ glucose, $0.5 \mathrm{~g}$ peptone, $0.3 \mathrm{~g}$ yeast extract, $0.1 \mathrm{~g}$ $\mathrm{KH}_{2} \mathrm{PO}_{4}$, and $0.05 \mathrm{~g}$ magnesium sulphate $\left(\mathrm{MgSO}_{4}\right)$ produced the highest biomass yield and COD reduction at $26.74 \mathrm{~g} \mathrm{litre}^{-1}$ and $79.12 \%$, respectively. The recorded density of yeast growth for this composition was $1.03 \times 10^{9} \mathrm{CFU} \mathrm{ml}{ }^{-1}$. This shows that the yeast cells have utilised more sugars and produced more biomass (Keturah et al., 2014). In contrast, the biomass yield, COD reduction, and protein content in control POME hydrolysate were 8.33 g litre $^{-1}, 62.22 \%$ and $11.05 \%$, respectively, No colony was formed in aliquot spotted agar plate indicating that the biomass and protein determined in the POME hydrolysate control was not affected by the yeast growth. For compositions $2(100 \%$ hydrolysed POME), the growth of yeast was observed in the medium but with lower biomass yield, since no glucose and nutrients were added into this medium. This indicated that the yeast growth is highly dependent on limited fermentable sugars available in POME hydrolysate with reducing sugar content of approximately $4 \mathrm{~g} / 100$ $\mathrm{ml}$. Previous study showed that lower yeast growth was observed when the fermentation media (papaya extract juice) were diluted with $400 \mathrm{ml}$ and 600 $\mathrm{ml}$ sterile water as compared by using undiluted juice as the fermentation medium. The poor cell growth in diluted fermentation substrate may be attributed to reduction of available sugars and in the concentration of growth factors (Ojokoh and Uzeh, 2005).

Composition 6 which contained $100 \mathrm{ml}$ untreated POME supplemented with $2 \mathrm{~g}$ glucose, $0.3 \mathrm{~g}$ yeast extract, $0.5 \mathrm{~g}$ peptone, $0.1 \mathrm{~g} \mathrm{KH}_{2} \mathrm{PO}_{4}$ and $0.05 \mathrm{~g} \mathrm{MgSO}_{4}$ produced the highest biomass yield (51.66 $\left.\mathrm{g} \mathrm{litre}^{-1}\right)$. However, the high biomass yield recorded may be contributed by the initial suspended solids that existed in the untreated POME samples. This can be seen from the raw POME control samples (29.93 $\mathrm{g} \mathrm{litre}^{-1}$ solid biomass). COD reduction during fermentation was relatively lower at $56.07 \%$. The growth of yeast was observed in this medium with the addition of $\mathrm{N}$ source (yeast extract and peptone) together with carbon source (existing COD) in the POME samples. COD reduction of $62.85 \%$ in medium 5 (100\% untreated POME) was highest among untreated POME samples. Since no additional carbon sources and nutrients were added into this medium, the yeast utilised any carbon, $\mathrm{N}$ and micronutrient sources that were readily available in the untreated POME samples. The yeast (S. cerevisiae) may also be able to hydrolyse complex carbohydrate in untreated POME into sugars that serve as carbon source in synthesising microbial biomass during the fermentation process (Aruna et al., 2017).

The biomass produced after fermentation was analysed for protein content. The initial protein content in untreated POME and POME hydrolysate were $17.26 \%$ and $11.05 \%$, respectively. The highest protein content was obtained in composition 3 $(24.79 \%)$. With this amount, the resulting biomass is quite suitable for animal feed use (Iwuagwu and Ugwuanyi, 2014). The protein yield in composition 3 was the highest $\left(7.34 \mathrm{~g} \mathrm{litre}^{-1}\right)$ among POME hydrolysate medium due to its highest biomass yield. Protein yield in untreated POME was higher $\left(11.8 \mathrm{~g} \mathrm{litre}^{-1}\right)$ than POME hydrolysate, but with lower protein increment $\left(5.45 \mathrm{~g} \mathrm{litre}^{-1}\right)$ compared to initial protein content prior to yeast fermentation. However, the biomass yield was comparable to GM although the protein content was much lower. This 
is due to $5 \%$ glucose was used as carbon source in GM whereas only 2\% glucose was added with $4 \%$ reducing sugar (mixed of glucose and pentose) in medium 3. Earlier study stated that S. cerevisiae preferentially utilises glucose as the source of carbon. However, following its depletion, it can utilise a wide variety of other carbons including non-fermentable compounds (Turcotte et al., 2009).

Table 5 shows that medium compositions affect the increment of biomass and protein yield after fermentation. The use of $100 \%$ POME hydrolysate supplemented with inorganic carbon and $\mathrm{N}$ source as well as micronutrient in fermentation medium (composition 3) gave substantial increase in biomass and protein yield of more than 3.44 and 7.74 folds, respectively. The crude protein content in that particular sample was $24.79 \%$. Nevertheless, composition 6 recorded the highest biomass and protein yield of 51.66 and $9.83 \mathrm{~g}$ litre $^{-1}$, respectively. The biomass and protein yield increment after yeast fermentation were only 1.71 and 1.89 folds, respectively. These findings demonstrated similar trend with a study by Aruna et al. (2017) in which fermented yam peels with $S$. cerevisae supplemented with $\mathrm{N}$ source produced $15.54 \%$ crude protein as compared to unfermented yam peels and nonsupplemented $S$. cerevisae fermented yam peels that produced $6.60 \%$ and $11.08 \%$ crude protein, respectively. In addition, COD reduction was not influenced by composition of the fermentation medium.

Compared to other studies presented in Table 6, this study managed to produce higher biomass but with lower protein content. This is because most of the biomass was in the form of suspended solid (readily present in the raw material). However, yeast fermentation seemed to significantly increase the protein content in POME hydrolysate from $11 \%$ to $29 \%$. For untreated POME substrate, the protein increment was from $17 \%$ to $24 \%$. The COD

TABLE 5. INCREMENT OF BIOMASS AND PROTEIN YIELD AFTER YEAST FERMENTATION IN HYDROLYSED POME

\begin{tabular}{cccc}
\hline Samples & Media & $\begin{array}{c}\text { Biomass yield increment } \\
\text { (fold) }\end{array}$ & $\begin{array}{c}\text { Protein yield increment } \\
\text { (fold) }\end{array}$ \\
\hline 1 & $50 \% \mathrm{HP}+50 \% \mathrm{GM}$ & $2.20 \pm 0.72$ & $4.90 \pm 1.62$ \\
2 & $100 \% \mathrm{HP}$ & $2.02 \pm 0.34$ & $3.34 \pm 0.44$ \\
3 & $\mathrm{HP}+2 \%$ glucose + YE + Peptone + minerals & $3.44 \pm 0.41$ & $7.74 \pm 1.07$ \\
4 & $50 \% \mathrm{UP}+50 \% \mathrm{GM}$ & $0.97 \pm 0.16$ & $1.05 \pm 0.19$ \\
5 & $100 \% \mathrm{UP}$ & $0.94 \pm 0.16$ & $1.28 \pm 0.17$ \\
\hline
\end{tabular}

Note: POME - palm oil mill effluent; COD - chemical oxygen demand; CP - control sample for untreated mixed raw POME (MRE); CHP - control sample for POME hydrolysate; UP - untreated MRE; HP - hydrolysed POME; YE - yeast extract; GM - growth medium.

TABLE 6. COMPARISONS ON YEAST AND FUNGAL BIOMASS PRODUCTIONS FROM DIFFERENT SUBSTRATES

\begin{tabular}{|c|c|c|c|c|c|}
\hline $\begin{array}{l}\text { Substrate/ } \\
\text { Microorganism }\end{array}$ & $\begin{array}{c}\text { Biomass yield } \\
\left(\mathrm{g} \mathrm{litre}^{-1}\right)\end{array}$ & $\begin{array}{c}\text { COD reduction } \\
(\%)\end{array}$ & $\begin{array}{l}\text { Protein content } \\
\qquad(\%)\end{array}$ & $\begin{array}{l}\text { Protein yield } \\
\left.\quad\left(\mathrm{g}_{\text {litre }}\right)^{-1}\right)\end{array}$ & References \\
\hline $\begin{array}{l}\text { Untreated POI } \\
\text { S. cerevisiae }\end{array}$ & $63.84 \pm 6.01$ & $59.02 \pm 5.34$ & $18.09 \pm 2.81$ & $11.80 \pm 1.55$ & This study \\
\hline $\begin{array}{l}\text { POME hydrolysate/ } \\
\text { S. cerevisiae }\end{array}$ & $28.92 \pm 3.43$ & $79.12 \pm 3.73$ & $24.79 \pm 1.31$ & $7.34 \pm 1.06$ & This study \\
\hline $\begin{array}{l}\text { POME/ } \\
\text { Saccharomyces sp. L3 }\end{array}$ & 4.42 & 83.00 & 27.00 & 1.19 & $\begin{array}{l}\text { Iwuagwu and } \\
\text { Ugwuanyi (2014) }\end{array}$ \\
\hline $\begin{array}{l}\text { Pineapple waste/ } \\
\text { S. cerevisiae }\end{array}$ & 5.71 & $\mathrm{n} / \mathrm{a}$ & $\mathrm{n} / \mathrm{a}$ & 2.76 & $\begin{array}{c}\text { Dhanasekaran et al. } \\
\text { (2011) }\end{array}$ \\
\hline $\begin{array}{l}\text { Cabbage juice/ } \\
\text { S. cerevisiae }\end{array}$ & 8.00 & $\mathrm{n} / \mathrm{a}$ & 35.00 & 2.00 & $\begin{array}{l}\text { Choi and Park } \\
\text { (2003) }\end{array}$ \\
\hline $\begin{array}{l}\text { Vegetable waste } \\
\text { hydrolysate/S. cerevisiae }\end{array}$ & 8.10 & $\mathrm{n} / \mathrm{a}$ & 41.30 & 3.35 & $\begin{array}{l}\text { Stabnikova et al. } \\
\text { (2005) }\end{array}$ \\
\hline $\begin{array}{l}\text { Potato wastewater/ } \\
\text { Candida utilis }\end{array}$ & 33.25 & $\mathrm{n} / \mathrm{a}$ & 36.70 & 12.20 & Kurcz et al. (2018) \\
\hline $\begin{array}{l}\text { Steriliser condensate/ } \\
\text { Isolated cellulolytic fungi }\end{array}$ & 8.30 & $\mathrm{n} / \mathrm{a}$ & 30.30 & 2.48 & $\begin{array}{l}\text { Cheah and Leslie } \\
\text { (1987) }\end{array}$ \\
\hline
\end{tabular}

Note: n/a - not available; POME - palm oil mill effluent; COD - chemical oxygen demand. 
reduction of $79.12 \%$ was comparable to Barker and Worgan (1981) with a reduction of 77\% COD during mycoprotein production from POME using Yarrowia lipolytica NCIM 3589 culture. On the other hand, COD reduction was slightly lower when compared to the use of POME for bioethanol and biogas production at $91 \%$ and $82 \%$, respectively (Alam et al., 2009; Prasertsan et al., 2017).

\section{CONCLUSION}

POME hydrolysate was utilised as medium for the production of microbial biomass protein, that is also known as crude SCP. Fermentation of mixed raw POME either in raw or hydrolysed form, using $S$. cerevisiae with and without the addition of carbon and $\mathrm{N}$ sources resulted in microbial protein production. However, higher yield was obtained when fermentation of the S. cerevisiae was carried out using undiluted POME hydrolysate as the substrate. The fermentation produced $28.92 \mathrm{~g} \mathrm{litre}^{-1}$ biomass with $24.79 \%$ protein content and consequently reduced organic pollutant up to $79.12 \%$ COD reduction. The yeast fermentation in undiluted hydrolysed POME supplemented with additional carbon and $\mathrm{N}$ sources recorded the highest increase in biomass and protein contents that of 3.44 and 7.74 folds, respectively. Considering these significant enhanced protein contents in the POME, it is a potential protein supplement in animal diet. Besides this, scale-up studies should be conducted in order to develop the present process, which would offer a low-cost and abundant substrate for SCP production.

\section{ACKNOWLEDGEMENT}

The authors wish to thank the Director-General of $\mathrm{MPOB}$ for his encouragement and permission to publish this article. Thanks are extended to NUTRADEC Laboratory staff for provided excellent technical assistance.

\section{REFERENCES}

Alam, M Z; Kabbashi, N A and Hussin, S N I S (2009). Production of bioethanol by direct bioconversion of oil-palm industrial effluent in a stirred-tank bioreactor. J. Ind. Microbiol Biotechnol., 36: 801-808.

Ali Amat, N A; Tan, Y H; Lau, W J; Lai, G S; Ong, C S; Mokhtar, N M; Sani, N A A; Ismail, A F; Goh, P S; Chong, K C and Lai, S O (2015). Tackling colour issue of anaerobically-treated palm oil mill effluent using membrane technology. J. Water Process Eng., 8: 221-226.
Anupama and Ravindra, P (2000). Value-added food: Single cell protein. Biotechnol. Adv., 18(6): 459-479.

APHA (2018). 5220 Chemical Oxygen Demand (COD). In Standard Methods for the Examination of Water and Wastewater. American Public Health Association.

Aruna, T E; Aworh, O C; Raji, A O and Olagunju, A I (2017). Protein enrichment of yam peels by fermentation with Saccharomyces cerevisiae (BY4743). Ann. Agric. Sci., 62(1): 33-37.

Ayeni, A O; Adeeyo, O A; Oresegun, O M and Oladimeji, T E (2015). Compositional analysis of lignocellulosic materials: Evaluation of an economically viable method suitable for woody and non-woody biomass. Am. J. Eng. Res., 4(4): 14-19.

Barker, T W and Worgan, J T (1981). The utilisation of palm oil processing effluents as substrates for microbial protein production by the fungus Aspergillus oryzae. European J. Appl. Microbiol. Biotechnol., 11(4): 234-240.

Cheah, S C and Leslie, O C (1987). Development of a process for palm oil mill steriliser condensate utilisation. Proc. of the National Symposium of Oil Palm By-product for Agro-based Industries. p. 203-220.

Chia, W Y; Chong, Y Y; Chew, K W; Vimali, E; Jayaram, M; Selvarajoo, A; Muthuvelu, K S; Varalakshmi, P; Show, P L and Arumugasamy, S K (2020). Outlook on biorefinery potential of palm oil mill effluent for resource recovery. J. Environ. Chem. Eng., 8(6): 104519.

Choi, M H and Park, Y H (2003). Production of yeast biomass using waste Chinese cabbage. Biomass Bioenergy, 25: 221-226.

Dhanasekaran, D; Lawanya, S; Saha, S; Thajuddin, N and Panneerselvam, A (2011). Production of single cell protein from pineapple waste using yeast. Innov. Rom. Food Biotechnol., 8: 26-32.

Iwuagwu, J O and Ugwuanyi, J O (2014). Treatment and valorization of palm oil mill effluent through production of food grade yeast biomass. J. Waste Manag., 2014: 1-9.

Izah, S C (2018). Feed potentials of Saccharomyces cerevisiae biomass cultivated in palm oil and cassava mill effluents. J. Bacteriol. Mycol. Open Access, 6(5): 287-293.

Izzi, A Z; Yusuf, N N A N; Ishak, W F W and Kim, H (2020). Box-Behnken-Design based optimization strategy for alkaline pretreatment of palm oil mill 
effluent for producing reducing sugar. IOP Conf. Ser.: Earth Environ. Sci., 596(1).

Kamal, S A; Md Jahim, J; Anuar, N; Hassan, O; Wan Daud, W R; Mansor, M F and Rashid, S S (2012). Pre-treatment effect of palm oil mill effluent (POME) during hydrogen production by a local isolate Clostridium butyricum. Int. J. Adv. Sci. Eng. Inf. Technol., 2: 325-331.

Kamyab, H; Din, M F M; Keyvanfar, A; Majid, M Z A; Talaiekhozani, A; Shafaghat, A; Lee, C T; Shiun, L J and Ismail, H H (2015). Efficiency of microalgae chlamydomonas on the removal of pollutants from palm oil mill effluent (POME). Energy Procedia, 75: 2400-2408.

Keturah, I; Sandrasegarampillai, B and Vasanthy, A (2014). Baker's yeast biomass production with rice as carbon and soy meal as nitrogen sources. Malays. J. Microbiol., 10(3): 205-214.

Khaw, T S; Hassan, M A and Ariff, A (2008). Enzymatic saccharification of pretreated solid palm oil mill effluent and oil palm fruit fiber. Pertanika J. Sci. Technol., 16(2): 157-169.

Kurcz, A; Blazejak, S; Kot, A M; Bzducha-Wrobel, A and Kieliszek, M (2018). Application of industrial wastes for the production of microbial single-cell protein by fodder yeast Candida utilis. Waste Biomass Valor., 9: 57-64.

Kushairi, A; Ong-Abdullah, M; Nambiappan, B; Hishamuddin, E; Bidin, M N I Z; Ghazali, R; Subramaniam, V; Sundram, S and Parveez, G K A (2019). Oil palm economic performance in Malaysia and R\&D progress in 2018. J. Oil Palm Res., 31(2): 165-194.

Ma, A N (1999). Treatment of palm oil mill effluent. Oil Palm and the Environment: A Malaysian Perspective (Singh, G; Lim, K H; Leng, T and David, L K eds.). Malaysian Oil Palm Growers' Council. Kuala Lumpur. p. 113-126.

Maehre, H K; Dalhein, L; Edvinsen, G K; Elvevoll, E O and Jensen, I-J (2018). Protein determination Method matters. Foods (Basel, Switzerland), 7(1): 5. DOI: 10.3390 / foods7010005

Miller, G L (1959). Use of dinitrosalicylic acid reagent for determination of reducing sugar. Anal. Chem., 31(3): 426-428.

Müller, J (2017). Dumas or Kjeldahl for reference analysis? Comparison and considerations for nitrogen/protein analysis of food and feed. Anal. beyond Meas., (June): 1-5.
Mun, W K; Rahman, N A; Abd-Aziz, S; Sabaratnam, V and Hassan, M A (2008). Enzymatic hydrolysis of palm oil mill effluent solid using mixed cellulases from locally isolated fungi. Res. J. Microbiol., 3(6): 474-481.

Nahrul Hayawin, Z; Nor Faizah, J; Ropandi, M and Astimar, A A (2017). A review on the development of palm oil mill effluent (POME) final discharge polishing treatments. J. Oil Palm Res., 29(4): 528-540.

Nasrullah, M; Singh, L; Krishnan, S; Sakinah, M and Zularisam, A W (2018). Electrode design for electrochemical cell to treat palm oil mill effluent by electrocoagulation process. Environ. Technol. Innov., 9: 323-341.

Noorshamsiana, A W; Nur Eliyanti, A; Fatiha, I and Astimar, A A (2017). A review on extraction processes of lignocellulosic chemicals from oil palm biomass. J. Oil Palm Res., 29(4): 512-527.

Noorshamsiana, A W; Astimar, A A; Nor Hayati, M; Nor Faizah, J; Mohamadiah, B and Norhayati, S (2013). Optimisation of enzymatic sludge palm oil recovery from palm oil mill effluent using response surface methodology. J. Oil Palm Res., 25(3): 348-356.

Numan, A H; Yahaya, H; Ngatiman, M; Nor Faizah, J; Noorshamsiana, A W and Rohaya, M H (2019). Assessment of the effluent polishing plant using a ultrafiltration membrane installed at a palm oil mill. Environ. Prot. Eng., 45(1): 155-170 .

Nurul Adela, B; Nasrin, A B and Loh, S K (2016). Palm oil mill effluent as a low - cost substrate for bioflocculant production by Bacillus marisflavi NA8. Bioresour. Bioprocess., 3: 2-8.

Nurul Adela, B; Loh, S K; Nasrin, A B and Jahim, J M (2020). Enzymatic hydrolysate of palm oil mill effluent as potential substrate for bioflocculant BM-8 production. Waste Biomass Valor., 11(1): 17-29.

Ojokoh, A O and Uzeh, R E (2005). Production of Saccharomyces cerevisiae biomass in papaya extract medium. Afr. J. Biotechnol., 4(11): 1281-1284.

Parthasarathy, S; Mohammed, R R; Chong, M F; Gomes, R L and Manickam, S (2016). A novel hybrid approach of activated carbon and ultrasound cavitation for the intensification of palm oil mill effluent (POME) polishing. J. Clean. Prod., 112: 12181226.

Patelski, P; Berłowska, J; Balcerek, M; DziekońskaKubczak, U; Pielech-Przybylska, K; Dygas, D and Jedrasik, J (2020). Conversion of potato industrywaste into fodder yeast biomass. Processes, 8(4): 453. 
Prasertsan, P; Khangkhachit, W; Duangsuwan, W; Mamimin, C and O-Thong, S (2017). Direct hydrolysis of palm oil mill effluent by xylanase enzyme to enhance biogas production using twosteps thermophilic fermentation under non-sterile condition. Int. J. Hydrog. Energy, 42(45): 27759-27766.

Saifuddin, N and Refal, H (2014). Microwave assisted alkaline pretreatment and microwave assisted enzymatic hydrolysis of palm oil mill effluent (POME) for optimum fermentable sugar yield. Chem. Sci. Trans., 3: 350-358.

Sharif, M; Zafar, M H; Aqib, A I; Saeed, M; Farag, M R and Alagawany, M (2021). Single cell protein: Sources, mechanism of production, nutritional value and its uses in aquaculture nutrition. Aquaculture, 531: 735885.

Silvamany, H; Harun, S; Mumtaz, T and Jahim, J M (2015). Recovery of fermentable sugars from palm oil mill effluent via enzymatic hydrolysis. Jurnal Teknologi, 77(33): 115-121.
Spalvins, K; Ivanovs, K and Blumberga, D (2018). Single cell protein production from waste biomass: Review of various agricultural by-products. Agron. Res., 16: 1493-1508.

Stabnikova, O; Wang, J; Ding, H B and Tay, J (2005). Biotransformation of vegetable and fruit processing wastes into yeast biomass enriched with selenium. Bioresour. Technol., 96: 747-751.

Turcotte, B; Liang, X B; Robert, F and Soontorngun, N (2009). Transcriptional regulation of nonfermentable carbon utilization in budding yeast. FEMS Yeast Res., 10: 2-13.

Zahrim, A Y; Nasimah, A and Hilal, N (2014). Pollutants analysis during conventional palm oil mill effluent (POME) ponding system and decolourisation of anaerobically treated POME via calcium lactate-polyacrylamide. J. Water Process Eng., 4: 159-165. 